O. Pohorielova, PhD (Law), Assist.

Taras Shevchenko National University of Kyiv, Kyiv, Ukraine

\title{
THE PROTECTION OF OWNERS' CORPORATE RIGHTS AND EMPLOYEES' LABOUR RIGHTS: JUDICIAL PRACTICE ANALYSIS
}

The article is devoted to the issue on protecting the employees' labour rights in case of an employment dispute, which is considered regarding corporate rights of company owners. The article emphasizes that during work employees are bearing more and more rights and obligations that are realized in different types of relationships. It is also stated that in case of disputes arising from employment relations, courts need to take into account basic factors of labour law.

The purpose of this article is to develop proposals for to improving the mechanism of for the protection of emplyees' labour rights. In order to achieve this goal, the author analyses judicial practice regarding the protection of employees' labour rights in disputes related to business entities' functioning, as well as it reveals the contractual nature of labour relations and formulates the proposals on creation of legal conditions for the protection of employees' labour rights.

The subject of the study is the judicial protection of company owners' corporate rights and the labour rights of employees. The object of the study is the protective legal relations that arise in the process of resolving labour disputes by the courts of Ukraine. The deductive method used in the work made it possible has allowed the author to substantiate the need for a clear distinction between labour and corporate rightslaw, considering labour disputes and as well as the necessity to take into account the specifics of the method of legal regulation in labour law, in particular the contractual nature of the entrenching of on rights and obligations.

The method of induction has revealed the theoretical and practical problems of the distinction between corporate and labour rights. The theoretical and prognostic method has been used to substantiate the proposals for the improvement of labour legislation to protect the labour rights of employees. Categories and methods of formal logic have been widely used in the work: concepts, definitions, proofs, judgments, analysis, synthesis, analogy, comparison, generalizations, etc.

The paper focuses on the judicial bodies' powers on the necessity to allocate the specialization of judges for the consideration of labor cases. Based on the case law analysis, the improvement of the national labour legislation on wrongful dismissal is proposed.

In fact, every court case in which labour disputes are settled has its own peculiarities and specifics, which in its turn requires the specialization of judges who have to consider labour disputes. It is the specialization of judges in Ukraine that will provide an opportunity not only to guarantee the emploees' labour rights, but to practically improve the mechanism for the protection of employees' labour rights enshrined in collective and employment agreements.

Keywords: a labour dispute, judicial jurisdiction, judges' specialization, labour rights, corporate rights, judicial practice.

Bulletin of Taras Shevchenko National University of Kyiv Legal Studies, 2019; 4 (111): 55-61

УДК: 349.6

DOI: https:doi.org/10.17721/1728-2195/2019/4.111-11
ISSN 1728-2195

(C) Taras Shevchenko National University of Kyiv, Publishing center "Kyiv University", 2019

Е. Позняк, канд. юрид. наук, доц. ORCID ID: 0000-0001-5515-4849

Київський національний університет імені Тараса Шевченка, Київ, Україна

\section{ЕКОЛОГО-ПРАВОВА КУЛЬТУРА ПРИРОДНОГО ЗАПОВІДАННЯ В УКРАЇНІ (НА ПРИКЛАДІ СТВОРЕННЯ ЧОРНОБИЛЬСЬКОГО РАДІАЦІЙНО-ЕКОЛОГІЧНОГО БІОСФЕРНОГО ЗАПОВІДНИКА)}

Проаналізовано новації законодавчого регулювання в Україні процесу створення і забезпечення діяльності Чорнобильського радіаційно-екологічного біосферного заповідника в межах зони відчуження та зони безумовного (обов'язкового) відселення.

Правовий режим біосферного заповідника забезпечує: національний і міжнародний рівень правової охорони та відтворення тваринного і рослинного світу й середовища його існування; збереження та відтворення "червонокнижних" об'єктів тваринного світу; виконання фундаментальних наукових досліджень і прогнозування подальших змін видового та популяційного стану тваринного світу; розвиток еколого-правової культури суспільства і громадян у результаті організації та проведення заповідником інформаційно-просвітницької, рекреаційної, туристичної, освітянсько-виховної, пізнавальної діяльності.

Однак біосферний заповідник було створено в межах території, яка тривалий час була екологічно та радіаційно небезпечною. Правовий режим Чорнобильської зони передбачає низку обмежень для проживання людини та заборону деяких видів діяльності. Зважаючи на це, зазначено необхідність глибшого дослідження питання про рівень безпечності перебування диких тварин і рослин у межах заповідника, розробки критеріїв екологічної та радіаційної безпеки об'єктів тваринного і рослинного світу.

Ключові слова: біологічне різноманіття, екологічна та радіаційна безпека, еколого-правова культура, природнозаповідний фонд, радіаційно забруднені території, тваринний і рослинний світ, Чорнобильська зона, Чорнобильський радіаційно-екологічний біосферний заповідник.

ВСТУП. У сучасних умовах поглиблення екологічної кризи особливої уваги з боку суспільства та держави потребують питання розвитку культури взаємовідносин людини та природи, забезпечення державою екологічної, ядерної та радіаційної безпеки. Відповідне опосередкування в праві форм, напрямів і особливостей такої взаємодії спрямоване на підвищення рівня еколого-правової культури.

Постановка проблеми. Однією з проблем розвитку еколого-правової культури в Україні $\epsilon$ усвідомлення суспільством необхідності посилення правової охорони всього біологічного різноманіття та середовища його існування. Важливими напрямами цієї охорони є: ура- хування міжнародно-правових та європейських підходів до визначення правового режиму особливо цінних об'єктів природи; узгодження умов використання об'єктів тваринного та рослинного світу, зокрема "червонокнижних"; охорона місць перебування диких тварин; забезпечення їхньої екологічної, у тому числі радіаційної безпеки; відновлення територій, що зазнали небезпечного техногенного впливу, насамперед радіоактивного, унаслідок Чорнобильської катастрофи; проведення наукової роботи, результати якої сприятимуть активізації освітянської, просвітницької, виховної та широкої інформаційної діяльності та підвищенню рівня екологічної культури суспільства і громадян. Найоптимальнішою 
видається саме природно-заповідна форма охорони біологічного різноманіття.

Аналіз останніх досліджень і публікацій. Проблеми еколого-правової культури та ії̈ елементів, у тому числі у сфері правової охорони та відтворення тваринного і рослинного світу, досліджували такі радянські та українські вчені, як В.ІІ.Андрейцев, Г.І.Балюк, П. О. Гвоздик О. С. Колбасов, С. С. Константініді, . М. Кравченко, М. В. Краснова, Н. Р. Малишева, В. Л. Мунтян, $\begin{array}{lll}\text { В.І. Олещенко, } & \text { В. В. Петров, А. К. Соколова, }\end{array}$ П. В. Тихий, Ю. С. Шемшученко, В.В.Шеховцов та ін. Правові проблеми природного заповідання у своїх дослідженнях розглядали М. Я. Ващишин, А. Й. Годованюк, О. М. Ковтун, Н. Д. Красіліч, Л. Я. Окорокова та ін. Проблеми правового регулювання відносин із забезпечення екологічної, ядерної та радіаційної безпеки людини та навколишнього природного середовища досліджували такі вчені, як Г. І. Балюк, А. І. Іойриш, О. Ю. Кронда, Ю. М. Крупка, С. Г. Плачкова, О. В. Сушик та ін. Важливими в дослідженні зазначеної проблематики є праці в інших сферах знань про взаємодію людини і природи, зокрема таких вчених, як Т. Л. Андрієнко, В. $€$. Борейко, В. І. Вернадський, М. А. Голубець, М. Ф. Реймерс, Т. В. Тимочко, Ю. Р. Шеляг-Сосонко, Ф. Р. Штільмарк та ін. Створенню Чорнобильського радіаційно-екологічного біосферного заповідника в Україні присвячена публікація вчених Джанфрранко Тамбуреллі (Gianfranco Tamburelli, м. Рим, Італія) та Т. О. Коваленко (м. Київ, Україна).

Проте наукові та практичні проблеми правової охорони й відтворення тваринного і рослинного світу в межах радіоактивно забруднених територій шляхом природного заповідання таких територій висвітлені недостатньо, не досліджувались вони й у контексті суспільної еколого-правової культури. Це обумовлює актуальність та специфіку запропонованої автором тематики даної публікації.

Метою статті $€$ здійснення аналізу соціальноправових передумов та особливостей створення Чорнобильського радіаційно-екологічного біосферного заповідника, охорони та відтворення тваринного і рослинного світу як важливих елементів біорізноманіття в його межах, забезпечення екологічної та радіаційної безпеки, підвищення рівня суспільної еколого-правової культури завдяки зазначеній діяльності. Для досягнення зазначеної мети в роботі поставлено завдання: дослідити наукові, нормативно-правові та практичні підходи представників правової та природничої сфрер знань до природного заповідання радіоактивно забруднених територій, створення заповідника, охорони та відтворення тваринного і рослинного світу в його межах, здійснення ним діяльності та підвищення рівня суспільної еколого-правової культури.

Предметом дослідження $\epsilon$ соціально-правові передумови й особливості природного заповідання на прикладі створення Чорнобильського радіаційно-екологічного біосферного заповідника, а також наукові, нормативно-правові та практичні підходи до діяльності цього заповідника у сфері охорони й відтворення тваринного і рослинного світу, забезпечення екологічної та радіаційної безпеки, підвищення рівня суспільної еколого-правової культури.

Об'єктом дослідження $є$ суспільні відносини, які виникають у сфері природного заповідання, на прикладі природного заповідання територій у межах зони відчуження та зони безумовного (обов'язкового) відселення крізь призму еколого-правової культури суспільства і людини.
Методологія дослідження. 3 огляду на міждисциплінарний характер даної статті в основу методології було покладено загальнонауковий діалектичний метод пізнання. Використано також такі наукові методи, як: хронологічний (показано розвиток правових засад природного заповідання територій у межах зони відчуження та зони безумовного (обов'язкового) відселення), аналізу й синтезу (розглянуто правове регулювання природно-заповідних відносин у сфері створення та функціонування Чорнобильського радіаційно-екологічного біосферного заповідника), формально-логічний (проведення порівнянь і узагальнень нинішньої практики та перспектив діяльності цього заповідника), статистичний (наведення цифрових показників щодо складу природно-заповідного фонду, наукових даних щодо біологічного різноманіття на території даного заповідника), прогностичний (пропозиції щодо прийняття концептуальних документів - джерел еколого-правової політики - щодо перспектив розвитку правового режиму територій та об'єктів природно-заповідного фонду в Чорнобильській зоні) тощо.

\section{ВИКЛАД ОСНОВНОГО МАТЕРІАЛУ}

Політико-правові підходи до природного заповідання в Україні та його законодавче забезпечення. Природне заповідання як функція державної екологічної політики України, правове забезпечення природнозаповідної справи, надання охоронного статусу територіям та об'єктам природно-заповідного фонду з їх включенням до складу екологічної мережі України спрямоване на збереження природи, біорізноманіття, довкілля для сьогоднішнього і майбутніх поколінь людей [9, с. 166]. Це відображено, насамперед, у Конституції України від 28 червня 1996 р. [1]. Згідно зі ст. 13 природні ресурси (а отже, і природно-заповідний фонд) $є$ об'єктами права власності Українського народу. Згідно зі ст. 16 держава бере на себе обов'язок із забезпечення екологічної безпеки і підтримання екологічної рівноваги на території нашої держави з подолання наслідків Чорнобильської катастрофи - катастрофи планетарного масштабу.

Сучасний стан природоресурсної, природоохоронної та антропоохоронної політики України визначається Основними засадами (стратегією) державної екологічної політики України на період до 2030 року (затв. законом України від 28 лютого 2019 р.). Стратегією наводяться такі дані стосовно біорізноманіття.

Займаючи менше 6 \% площі Європи, Україна володіє близько $35 \%$ ії біологічного різноманіття. Біосфрера України нараховує більше 70 тисяч видів флори і фрауни, зокрема фрлори - понад 27 тисяч видів, фрауни понад 45 тисяч видів. Протягом останніх років спостерігається збільшення кількості видів рослин і тварин, занесених до Червоної книги України (розділ I). Низка положень цього документа характеризують стан природного заповідання територій і формування національної екологічної мережі, збереження біологічного та ландшафтного різноманіття у нашій державі загалом. Так, до складу природно-заповідного фронду входять 8246 територій та об'єктів; їхня загальна площа 3,98 млн га, це 6,6 \% загальної площі країни; 402,5 тис. га знаходяться у межах акваторії Чорного моря. Даною Стратегією наголошується, що частка земель природно-заповідного фонду в Україні $\epsilon$ недостатньою і залишається значно меншою, ніж у більшості держав - членів Європейського Союзу, де частка таких земель становить у середньому 21 \% їхньої площі.

Стає зрозумілим, що невиконаними залишились положення попереднього документа, чинність якого спливає, - Основних засад (стратегії) державної екологічної політики України на період до 2020 р., затв. Законом 
України від 21 грудня 2010 р. У цьому документі зазначалась необхідність збільшення площ земель національної екомережі, що має, насамперед, відбуватися в результаті розширення існуючих та створення нових об'єктів природно-заповідного фонду (розд. 1); про розширення площі природно-заповідного фонду до $15 \%$ загальної території країни у 2020 р. (розд. 3).

Учасниками парламентських слухань на тему "Пріоритети екологічної політики Верховної Ради України на наступні п'ять років", які відбулись 27 листопада 2019 р., неодноразово піднімалось питання про необхідність створення нових і розширення існуючих територій природно-заповідного фонду, створення мережі таких територій та об'єктів, їх нових категорій, які $€$ у Європі. Дане завдання увійшло до топ-п'ятірки завдань, визначених Міністерством енергетики та захисту довкілля України. Окремо приділялась увага питанням розвитку правового режиму Чорнобильського радіаційно-екологічного біосферного заповідника, що входить до завдань Державного агентства України 3 управління зоною відчуження.

Законом України "Про охорону навколишнього природного середовища" від 25 червня 1991 р. запроваджено особливу охорону природних територій та об'єктів, що мають велику екологічну цінність, як унікальних і типових природних комплексів, для збереження сприятливої екологічної обстановки, попередження та стабілізації негативних природних процесів і явищ. Передбачається також, що природні території та об'єкти, що підлягають особливій охороні, утворюють єдину територіальну систему і включають території та об'єкти природно-заповідного фонду, курортні та лікувально-оздоровчі, рекреаційні, водозахисні, полезахисні та інші типи територій та об'єктів, що визначаються законодавством України (ч. 1, 2 ст. 60).

Автори коментаря до цього закону зазначають розробку країнами світу національних і міжнародних форм охорони природного середовища та заходів, які прийнято визначати консервативною чи заповідною формою охорони природного середовища. Ця форма природоохоронної діяльності історично є первісною, адже саме 3 неї розпочиналася організована діяльність зі збереження природи. Із часом заповідна форма охорони природного середовища не тільки не втратила свого значення, а навпаки, набула поширення, стала більш різноплановою, до неї додалися близькі консервативні способи охорони природи, що забороняють чи обмежують господарську діяльність на певних територіях, утворюють баp'єр для поширення її негативних впливів на екологічні системи інших територій та об'єктів, ффіксують на них сприятливий для екосистем стан [7, с. 313].

Погоджуємось із думкою вчених про те, що діяльність, спрямована на подолання наслідків аварії на Чорнобильській AEC, є унікальним досвідом. 31986 р. організаціями та програмами Організації Об'єднаних Націй, Європейського Союзу та Співробітництва з розвитку різних країн, а також неурядовими організаціями та фондами фактично було започатковано й упроваджено понад двісті різних науково-дослідних і допоміжних проектів у відповідних сорерах, а саме: охорони здоров'я, ядерної безпеки, соціально-психологічної допомоги, економічної реабілітації, відновлення інформації й довкілля, контролю якості продуктів харчування [14].

Діяльність із природного заповідання в Україні забезпечується нормами законів України "Про природнозаповідний фонд України" від 16 червня 1992 р., "Про екологічну мережу України" від 24 червня 2004 р., "Про тваринний світ" від 13 грудня 2001 р., "Про рослинний світ" від 9 квітня 1999 р., "Про Червону книгу України" від 7 лютого 2002 р., "Про захист тварин від жорстокого поводження" від 21 лютого 2006 р., Земельним кодексом України від 25 жовтня 2001 р., Кодексом України про надра від 27 липня 1994 р., Водним кодексом України від 6 червня 1995 р., Лісовим кодексом України в редакції Закону України від 08 лютого 2006 р. та ін.

Зазначені положення національного законодавства відповідають нормам низки джерел міжнародного екологічного права, таких як Конвенція ООН про біологічне різноманіття від 5 червня 1992 р. (м. Ріо-де-Жанейро, Бразилія; ратиф. Законом України від 29 листопада 1994 р.); Конвенція ООН про охорону дикої флори та фауни і природних середовищ існування у Європі від 19 вересня 1979 р. (м. Берн, Швейцарія; Україна приєдн. згідно із Законом України від 29 жовтня 1996 р.); Конвенція про водно-болотні угіддя, що мають міжнародне значення, головним чином як середовища існування водоплавних птахів, від 2 лютого 1971 р. (м. Рамсар, Іран; Україна $є$ правонаступницею СРСР щодо участі в ній згідно із Законом України від 29 жовтня 1996 р.); Конвенція про збереження мігруючих видів диких тварин від 23 червня 1979 р. (м. Бонн, Німеччина; Україна приєдн. згідно із Законом України від 19 березня 1999 р.).

На визначення та збереження особливої заповідної території як місця, де застосовуються необхідні заходи збереження для підтримки чи відновлення у сприятливому стані природних середовищ існування та/або популяцій видів, для яких визначено це місце (у процесі створення Єдиної Європейської екологічної мережі особливо заповідних територій NATURA-2000, Смарагдової мережі (Emerald)), спрямовані положення директив Ради Європи 79/409/EEC про збереження диких птахів та 92/43/EEC про збереження природних середовищ існування дикої фауни та флори $[5 ; 6]$.

Соціально-правові передумови створення Чорнобильського радіаційно-екологічного біосферного заповідника. Науково-технічний прогрес, як відомо, приніс нові загрози для існування усього живого на нашій планеті, найбільші 3 яких - ядерна та радіаційна. Аналізуючи правові аспекти забезпечення ядерної та радіаційної (радіоекологічної) безпеки в Україні після катастрофи на Чорнобильській AEC, проф. Г.І. Балюк наголошувала на необхідності формування системи науково-технічних, економічних, організаційних, державно-правових та інших соціальних заходів забезпечення регулювання радіаційно небезпечної діяльності в Україні. Радіоекологічну безпеку вчена розглядає як найбільш значущий елемент екологічної безпеки в національному та глобальному масштабі, тому вкрай важливими $є$ забезпечення правового регулювання радіаційно небезпечної діяльності, встановлення режиму використання ядерної енергії з метою збереження життя і здоров'я людини, захист довкілля від радіоактивного забруднення внаслідок міграції радіоактивних речовин у біосфері та їх накопичення живими організмами [2, с. 8-9].

Однією з новацій правового регулювання відносин у сфері охорони тваринного і рослинного світу шляхом заповідання території, де вони перебувають та зростають, стало створення в Україні Чорнобильського радіаційно-екологічного біосферного заповідника. Із прийняттям Закону України "Про внесення змін до деяких законодавчих актів України щодо врегулювання окремих питань правового режиму території, що зазнала радіоактивного забруднення внаслідок Чорнобильської катастрофи" від 14 липня 2016 р. з'явилась нова редакція ст. 11 Закону України "Про правовий режим території, що зазнала радіоактивного забруднення внаслідок 
Чорнобильської катастрофи" від 27 лютого 1991 р. У цій нормі встановлюється, що з метою здійснення наукових досліджень у сфері охорони навколишнього природного середовища, збереження природної різноманітності ландшафтів, генофонду тваринного і рослинного світу, підтримання загального екологічного балансу, забезпечення фонового моніторингу навколишнього природного середовища у зоні відчуження, зоні безумовного (обов'язкового) відселення відповідно до законодавства можуть створюватися території та об'єкти природно-заповідного фонду. Ідеться також про те, що в межах таких територій та об'єктів здійснюються виключно види діяльності, визначені у відповідних положеннях про них, з урахуванням обмежень та в порядку, встановленому цим законом. Охорона та забезпечення дотримання особливого природоохоронного режиму в межах таких територій та об'єктів здійснюється відповідно до законодавства (ч. 2, 3 ст. 11).

Закон України "Про природно-заповідний фонд України" також було доповнено згідно із зазначеним вище законом окремими нормами. Зокрема завдання, особливий природоохоронний режим територій та об'єктів природно-заповідного фонду, які створюються на територіях зони відчуження та зони безумовного (обов'язкового) відселення території, що зазнала радіоактивного забруднення внаслідок Чорнобильської катастрофи, визначаються у положеннях про них, що затверджуються відповідно до Закону України "Про правовий режим території, що зазнала радіоактивного забруднення внаслідок Чорнобильської катастрофи" (ч. 3 ст. 5). На землях територій та об'єктів природно-заповідного фонду, які створюються в зоні відчуження та зоні безумовного (обов'язкового) відселення території, що зазнала радіоактивного забруднення внаслідок Чорнобильської катастрофи, забороняється будь-яка діяльність, що не забезпечує режим радіаційної безпеки (ч. 3 ст. 7).

Історично потреба в природному заповіданні Чорнобильської зони виникла ще задовго до оголошення самого заповідника. Уже через п'ять років після аварії на ЧАЕС дослідники констатували поступове відтворення тваринного і рослинного світу. Сприятливими умовами для цього стали евакуація населення й припинення тут господарської діяльності. Вчені зафіксували зростання чисельності типових і появу рідкісних видів флори та фауни. Прогноз на майбутнє був сприятливий - очікувалось повільне перетворення антропогенних ландшафтів на природні комплекси, притаманні Поліссю. Уже через 20 років після аварії на ЧАЕС територія у кілька сотень тисяч гектарів сама по собі стала заповідною: там знайшли прихисток і комфортні умови для розмноження сотні видів не тільки типових, а й рідкісних "червонокнижних" тварин [3].

3 огляду на це створення у 2007 р. у межах Чорнобильської зони загальнозоологічного заказника юридично стало початком формування особливого правового режиму об'єктів та територій, які оголошувались заповідними. Відповідно до Указу Президента України "Про оголошення природної території загальнозоологічним заказником загальнодержавного значення "Чорнобильський спеціальний" від 13 серпня 2007 р. № 700/2007 природну територію площею 48870 га в межах зони відчуження і зони безумовного (обов'язкового) відселення (Київська обл.) було оголошено загальнозоологічним заказником загальнодержавного значення "Чорнобильський спеціальний" (п. 1). Метою створення заказника стало збереження унікальних властивостей лісових насаджень зони відчуження і зони безумовно- го (обов'язкового) відселення в межах Київського Полісся, що $€$ найбільшим в Україні резерватом дикої фауни, яка потребує охорони та регулювання чисельності, відповідно до ст. 53 Закону України "Про природно-заповідний фонд України" (Преамбула).

Підвищення ступеню захищеності біологічного різноманіття зазначеної території загалом, збільшення площі територій природно-заповідного фонду, розвиток наукових досліджень стали можливими завдяки зусиллям науковців і екологічно спрямованої громадськості вже менш ніж через десять років із часу існування заказника "Чорнобильський спеціальний".

Постановою Верховної Ради України від 13 квітня 2016 р. № 1089-VIII було схвалено рекомендації парламентських слухань на тему "30 років після Чорнобиля: уроки та перспективи", які відбулися 16 березня 2016 р. Подолання наслідків Чорнобильської катастрофи учасниками парламентських слухань було визнано одним із пріоритетів державної політики України. Рекомендувалось законодавчо врегулювати проблемні питання: провадження наукової та природоохоронної діяльності на території зони відчуження та безумовного (обов'язкового) відселення; міжнародне наукове співробітництво; природно-заповідну діяльність; активізацію роботи щодо створення Чорнобильського біосферного заповідника (підпункти 1 і 16 п. 1).

Правові засади діяльності Чорнобильського радіаційно-екологічного біосферного заповідника. Відповідно до Указу Президента України "Про створення Чорнобильського радіаційно-екологічного біосферного заповідника" від 26 квітня 2016 р. № 174/2016 метою створення зазначеного заповідника стало: збереження в природному стані найбільш типових природних комплексів Полісся, забезпечення підтримки та підвищення бар'єрної функції Чорнобильської зони відчуження та зони безумовного (обов'язкового) відселення, стабілізація гідрологічного режиму та реабілітація територій, забруднених радіонуклідами, сприяння організації та проведенню міжнародних наукових досліджень (Преамбула).

Заповідник відповідно до п. 1 зазначеного указу було створено в Іванківському і Поліському районах Київської області в межах зони відчуження і зони безумовного (обов'язкового) відселення території, що зазнала радіоактивного забруднення внаслідок Чорнобильської катастрофи. До території даного заповідника погоджено в установленому порядку включення 226964,7 га земель державної власності, що перебувають у постійному користуванні у Державного агентства України з управління зоною відчуження, вилучаються у цього землекористувача та надаються біосферному заповіднику в постійне користування.

Положення про Чорнобильський радіаційно-екологічний біосферний заповідник було затверджено наказом Міністерства екології та природних ресурсів України від 3 лютого 2017 р. № 43 [8]. У ньому зазначається, що заповідник $є$ бюджетною, неприбутковою природоохоронною, науково-дослідною установою загальнодержавного значення і створений з метою збереження у природному стані найбільш типових природних комплексів біосфери, здійснення фонового екологічного моніторингу, вивчення навколишнього природного середовища, його змін під впливом антропогенних факторів (п. 1.2). Заповідник включається в установленому порядку до Всесвітньої мережі біосферних резерватів у рамках програми ЮНЕСКО "Людина і біосфера" та набуває міжнародного статусу (п. 1.3). Заповідник нале- 
жить до сорери управління Державного агентства України з управління зоною відчуження (п. 1.5).

Директор Чорнобильського радіаційно-екологічного біосферного заповідника зазначає, що зона відчуження - територія унікальна. За тридцять років природа там відновилася, але вона все ж залишається забрудненою. Серед завдань заповідника він вбачає два пріоритетні завдання - збереження тамтешньої флори й фауни та недопущення поширення радіонуклідів на чисті території, тобто виконання ним бар'єрнозахисних фрункцій [12]. Створений у межах 30-кілометрової зони відчуження та найбільший за територією в Україні заповідник став базисом для надзвичайно важливого природного експерименту, унікального не тільки для нашої країни, але й для всього світу, свого роду "територією відродження" [3].

Сьогодні, за даними вчених Чорнобильського радіаційно-екологічного біосферного заповідника, на його території зафіксовано більше 320 видів хребетних тварин (із загалом 410, що зустрічаються у регіоні), з яких 55 видів (з 97 можливих) занесені до Червоної книги України. Популяція копитних, хижих та інших видів диких тварин збільшилася до найвищого рівня за всю історію спостережень. Повернулися рись і ведмідь. Значно зросли популяції лося, благородного оленя, кабана, козулі. Поширились рідкісні птахи - орлан-білохвіст, підорлик, чорний лелека, сірий журавель, пугач та ін. Тут мешкає 14 видів рукокрилих, деякі з яких (ставковий кажан Pond Bat, широковушка Barbastelle Bat i великий кажан Greater Noctule) рідкісні навіть для Європи [3].

У той же час основна увага науковців зосереджена на вивченні рідкісних та типових видів фауни - великих хижаків (бурий ведмідь, рись, вовк) і копитних (лось, олень, косуля), популяція яких за останні роки зросла в кілька разів. Значний інтерес у науковців та відвідувачів зони відчуження викликає унікальна, створена у 90-ті рр. минулого століття вільна популяція коней Пржевальського. 3 огляду на зазначене сьогодні видовий склад тварин цієї території відповідає природній фауні даного географрічного регіону - Полісся [13].

Територія, на якій розташований Чорнобильський радіаційно-екологічний біосферний заповідник - особлива історико-етнографічна область України, край дрімучих лісів і непрохідних боліт, де ще збереглися найдавніші релікти праслов'янської та проукраїнської культури [3], де зростає полин-чорнобиль, який ще здавна викликає в українців сум і незбагненну жалобу [11, с. 117]. Українське Полісся є постійним об'єктом вивчення дослідників-археологів, істориків, фольклористів та етнографрів, а віднедавна - і фахівців природничого спрямування, які активно займаються вивченням рослинного і тваринного світу, що в екстремальних умовах підвищеної радіації, відсутності людей та їхньої діяльності зазнає змін [3].

Учені-природничники зазначають, що на території заповідника ми маємо зараз єдиний реальний шанс відновити квазіприродні екосистеми. Аналогічні їм існували близько 5-2 тис. років тому в лісовій зоні Європи. Програма "Фауна" (2000) значною мірою передбачає можливість реконструкції подібних екосистем шляхом відновлення великих фрітофагів (кінь Пржевальського, зубр, аналоги тура), популяції яких вдасться значно збільшити вже в найближчі 30 років [4].

Сучасний стан та перспективи розвитку правового забезпечення діяльності Чорнобильського радіаційно-екологічного біосферного заповідника. Сьогодні варто наголосити на тому, що процес формування правового механізму природного заповідання Чорнобильської зони й забезпечення екологічної та радіаційної безпеки в ії̈ межах триває і розвивається. За даними адміністрації Чорнобильського радіаційно-екологічного біосорерного заповідника, на відміну від інших об'єктів природно-заповідного фронду України, він виконуватиме не тільки свою основну функцію - збереження місцевого біорізноманіття, але й стане важливим елементом "лабораторії просто неба", якою є вся зона відчуження. 3 огляду на це визначено три пріоритетні напрями, за якими заповідник буде розвиватись у найближчі роки: 1) природоохоронний - збереження у природному стані найбільш типових природних комплексів Полісся та природної різноманітності ландшафтів, генофонду тваринного і рослинного світу; підтримання загального екологічного балансу, що забезпечить підвищення бар'єрної функції зони відчуження й зони безумовного (обов'язкового) відселення; стабілізація гідрологічного режиму та реабілітація територій, забруднених радіонуклідами; 2) науково-дослідницький - екологічний моніторинг навколишнього природного середовища, інвентаризація об'єктів фрлори та фрауни, екосистем; ведення літопису природи; розроблення наукових рекомендацій щодо збереження і відтворення рідкісних видів рослинного і тваринного світу, відновлення природних екосистем; підготовка наукових матеріалів та рекомендацій, необхідних для провадження екологічної освітньо-виховної роботи та інших видів діяльності заповідника; 3) інформаційнопросвітницький - поширення знань і підвищення обізнаності щодо цінностей біологічного й ландшафтного розмаїття заповідника, формування екологічної свідомості й виховання поваги до природи [13].

Стосовно проведення заповідником екологічної освітньо-виховної роботи та здійснення інформаційнопросвітницького й рекреаційного напрямів діяльності, які сприяють підвищенню рівня екологічної та екологоправової культури суспільства та громадян, слід зазначити їх відповідність до визначених чинним законодавством та усталених підходів до діяльності біосферних заповідників в Україні. Такими нормативно-правовими актами є: наказ Мінприроди України "Про затвердження Положення про рекреаційну діяльність у межах територій та об'єктів природно-заповідного фонду України" від 22 червня 2009 р. № 330 (зареєстр. у Мін'юсті України 22.07.2009 р. за № 679/16695); наказ Мінприроди України "Про затвердження Положення про екологічну освітньо-виховну роботу установ природно-заповідного фонду" від 26 жовтня 2015 р. № 399 (зареєстр. у Мін'юсті України 11.11.2015 р. за № 1414/27859); наказ Мінприроди України "Про затвердження Положення про наукову та науково-технічну діяльність природних і біосферних заповідників та національних природних парків" від 29 жовтня 2015 р. № 414 (зареєстр. у Мін'юсті України 18.11.2015 р. за № 1444/27889).

Положенням про Чорнобильський радіаційноекологічний біосферний заповідник зокрема передбачається: підготовка наукових матеріалів та рекомендацій, необхідних для провадження екологічної освітньовиховної роботи (6.3); організація екологічної просвіти серед відвідувачів, сприяння формуванню у рекреантів екологічної культури, бережливого та гуманного ставлення до національного природного надбання (п. 8.2); участь у міжнародному співробітництві у здійсненні еколого-виховної діяльності (п. 12.1). Основними напрямами та фрормами діяльності, передбаченими окремим пунктом - "Екологічна освітньо-виховна робота" (п. 7), є: формування наукових знань, поглядів і переконань, які за- 
кладають основи відповідального ставлення до навколишнього природного середовища i, зокрема, територій та об'єктів природно-заповідного фонду України (п. 7.2); організація екологічних освітньо-виховних екскурсій облаштованими еколого-освітніми стежками та маршрутами, організація і проведення масових природоохоронних та екологічних освітньо-виховних заходів, тематичних науково-практичних заходів за участю громадськості, учнівської та студентської молоді (п. 7.5) та ін.

Звісно ж, з метою виконання біосферними та природними заповідниками, національними природними парками та іншими установами природно-заповідного фонду України, у тому числі даним заповідником, своїх завдань потрібні наукові підходи вчених різних напрямів та сорер знань. Незважаючи на те, що концептуальні ідеї Програми перспективного розвитку заповідної справи в Україні ("Заповідники"), затвердженої Постановою Верховної Ради України від 22 вересня 1994 р. № 177/94-ВР, не втратили свого значення й на сьогодні, необхідно оновити зазначені підходи до природного заповідання. У зв'язку з цим підтримуємо пропозиції дослідників природно-заповідної проблематики стосовно необхідності розробки та затвердження національної Концепції заповідної справи, орієнтованої на міжнародні стандарти $[9$, с. $168 ; 10$, с. 44]. У даному документі пропонуємо передбачити і розділ, присвячений особливостям правового режиму територій та об'єктів природнозаповідного фонду, розміщених у Чорнобильській зоні.

На наш погляд, продовжує залишатись актуальним питання про необхідність розробки і прийняття Стратегії подолання наслідків Чорнобильської катастрофи та відродження територій, що зазнали радіоактивного забруднення. Про це зазначається в п. 1 Указу Президента України "Про додаткові заходи щодо перетворення об'єкта "Укриття" на екологічно безпечну систему та відродження територій, що зазнали радіоактивного забруднення внаслідок Чорнобильської катастрофи від 13 квітня 2016 р. № 141/2016. Стратегія має бути спрямована, зокрема, на: унормування питань радіологічної реабілітації територій, що зазнали радіоактивного забруднення; активізацію наукових досліджень у сферах ядерної та радіаційної безпеки, впливу іонізуючого випромінювання на людину та навколишнє природне середовище.

Нещодавно прийнятим Указом Президента України "Про додаткові заходи з відродження територій, що зазнали радіоактивного забруднення внаслідок Чорнобильської катастрофи, із соціального захисту постраждалих осіб, безпечного поводження з радіоактивними відходами" від 5 липня 2018 р. №196/2018 наголошувалось на необхідності вжиття заходів, спрямованих на реабілітацію та відродження територій, що зазнали радіоактивного забруднення внаслідок Чорнобильської катастрофри. До цих заходів було віднесено, крім схвалення до кінця 2018 р. проекту зазначеної нами вище Стратегії, також опрацювання в установленому порядку питання щодо створення транскордонного українсько-білоруського біосферного резервату на територіях, що зазнали радіоактивного забруднення внаслідок Чорнобильської катастрофи (п. 3). Вчені відмічають винятковий інтерес, який викликає ідея створення транскордонного біосферного заповідника з Білоруссю, адже це підтверджує велику актуальність програми МАВ ЮНЕСКО та закликає до подальших роздумів над великим потенціалом у частині територіального управління, що пропонується транскордонними заповідними зонами та міжнародними парками [14].

У той же час особливу увагу зазначеним вище Указом було приділено питанням сприяння розвитку Чорнобильського радіаційно-екологічного біосферного заповідника як унікального природно-заповідного об'єкта. У переліку запланованих у п. 5 Указу заходів передбачається: проведення до кінця 2018 р. робіт з радіоекологічного моніторингу територій, що зазнали радіоактивного забруднення внаслідок Чорнобильської катастрофи та на яких створено Чорнобильський радіаційноекологічний біосфрерний заповідник, з метою оцінки та визначення перспектив їхнього подальшого розвитку; вивчення питання щодо вдосконалення системи управління та функціонування Чорнобильського радіаційноекологічного біосфрерного заповідника.

Хоча дані завдання до кінця минулого року повністю виконані не були, однак важливість їх здійснення у поточному та наступних роках не викликає сумніву. До того ж перелічені заходи потребують державно-правових, організаційних, фінансових, техніко-технологічних і багатьох інших гарантій забезпечення.

ВИСновкИ. Підсумовуючи все зазначене вище, беручи до уваги поки що нетривалий час функціонування Чорнобильського радіаційно-екологічного заповідника, зазначимо, що даний біосферний заповідник було створено в межах території, яка тривалий час, із 1986 р. (а її частина й по сьогодні), була екологічно та радіаційно небезпечною для проживання людини. Правовий режим Чорнобильської зони передбачав і досі передбачає низку обмежень для проживання людини та заборону деяких видів діяльності.

У результаті формування правового механізму охорони та відтворення біорізноманіття радіоактивно забрудненої внаслідок Чорнобильської катастрофи частини території нашої держави на законодавчому рівні було визначено як найдієвіший спосіб природне заповідання частини Чорнобильської зони. Правовий режим біосферного заповідника забезпечує: національний та міжнародний рівень правової охорони і відтворення тваринного і рослинного світу, середовища його існування; збереження та відтворення "червонокнижних" об'єктів тваринного світу; проведення фундаментальних наукових досліджень і прогнозування подальших змін видового та популяційного стану тваринного і рослинного світу; розвиток еколого-правової культури суспільства і громадян у результаті організації та проведення зазначеним заповідником інформаційно-просвітницької, рекреаційної, туристичної, освітянсько-виховної, пізнавальної та інших видів діяльності.

На нашу думку, із внесенням відповідних змін і доповнень до законодавства розпочато формування нового правового механізму природного заповідання на радіаційно забруднених землях і нового напряму еколого-правової культури - правової культури природного заповідання територій, де стались надзвичайні екологічні ситуації.

Список використаних джерел:

1. Нормативно-правові акти наведено у відповідності до офріційного сайту Верховної Ради України. URL: http://www.rada.gov.ua (дата звернення: 13.11.2019).

2. Балюк Г.І. Правові аспекти забезпечення ядерної та радіаційної (радіоекологічної) безпеки в Україні: монографрія. К.: Віпол. 1997. $196 \mathrm{c}$.

3. В Мінприроди відкрилася виставка, присвячена створенню Чорнобильського радіаційно-екологічного біосферного заповідника URL: file://localhost/E:/3\%20робстолу червень\%202019/B\%20Мінприроди\% 20відкрилася\%20виставка,\%20присвячена\%20створенню\%20Чорнобил ьського\%20радіаційно-екологічного\%20біосферного\%20заповідника\% 
20-\%20Новини\%20-\%20Міністерство\%20екології\%20та\%20природних\% 20ресурсів\%20України.mht (дата звернення: 13.11.2019).

4. Воробйов Є.О. Екосистеми Чорнобильського радіаційноекологічного біосферного заповідника: кризові явища минулого i сучасності та шляхи оптимізації / Є.О. Воробйов, С.М. Бідна, Д.О. Вишневський, С.О. Євдокимова, О.А. Борсук. URL: https://zapovidnyk.org.ua/index.php?fn=novp\&f=php\&pid=2019-04-16-1932-40-3325 (дата звернення: 13.11.2019).

5. Директива Ради Європи 79/409/EEC про збереження диких птахів. URL: https://menr.gov.ua/news/31295.html (Дата звернення: 13.11.2019).

6. Директива Ради Європи 92/43/EEC про збереження природних середовищ існування і дикої фауни та флори. URL: https://menr.gov.ua/news/31295.html (дата звернення: 13.11.2019).

7. Науково-практичний коментар до Закону України "Про охорону навколишнього природного середовища" / Н.Р. Малишева, М.І. Єрофеєв. Х: Право. 2017. 417 с

8. Положення про Чорнобильський радіаційно-екологічний біосферний заповідник, затверджене Наказом Міністерства екології та природних ресурсів України від 3 лютого 2017 р. № 43. URL: http://zapovidnyk.org.ua/index.php?land=uk\&fn=novp\&pid=2019-04-16-2004-58-7371 (дата звернення: 13.11.2019).

9. Позняк Е.В. Проблеми еколого-правової культури природнозаповідної справи в Україні. Актуальні проблеми екологічного, земельного та аграрного законодавства в сучасних умовах: матеріали "круглого столу", присвяч. 90-річчю з дня народж. д-ра юрид. наук, проф., чл.-кор. НАПрН України В.К. Попова (Харків, 1 берез. 2019 р.) / за заг. ред. А.П. Гетьмана і М.В. Шульги. Х.: Право. 2019. С. $166-169$

10. Правовий режим природно-заповідного фонду України: історія формування, юридичні аспекти та закордонний досвід (посібник) / За заг. ред. О. Кравченко. Львів: Видавництво "Компанія "Манускрипт". 2017. 92 c.

11. Сніжко В.В. Нариси з психоетнічної екології України. К.: Веселка. 2001. 334 с.

12. Т. Мельничук: "Із зони відчуження намагаємося зробити зону відродження": Чим живе сьогодні, що планує на майбутнє та як долає перешкоди новостворений заповідник: інтерв'ю очільника Чорнобильського радіаційно-екологічного біосферного заповідника Т. Мельничука журналу "Пожежна та техногенна безпека". URL: https://zapovidnyk.org.ua/index.php?fn=novp\&f=php\&pid=2019-04-16-1958-58-9209 (дата звернення: 13.11.2019).

13. Чорнобильський радіаційно-екологічний біосферний заповідник. URL: https://zapovidnyk.org.ua/ (дата звернення: 13.11.2019).

14. Kovalenko T.O., Tamburelli G. La creazione di una riserva UNESCO della biosfera in Ucraina. Gazzetta Ambiente (Iталія). 2018. № 2 135-144. URL: http://www.gazzettaambiente.it/scheda.cfm?id=1248\&la_ creazione_di_una_riserva_unesco_della_biosfera_in_ucraina (Dama $3 в е р-$ нення: 13.11.2019).

\section{References:}

1. The normative legal acts are presented in accordance with the official site of the Verkhovna Rada of Ukraine. URL: http://www.rada.gov.ua (data zvernennia: 13.11.2019) (in Ukrainian).

2. Baliuk H.I. Pravovi aspekty zabezpechennia yadernoi ta radiatsiinoi (radioekolohichnoi) bezpeky $v$ Ukraini [Legal aspects of ensuring nuclear and radiation (radioecological) safety in Ukraine]: monohrafia. K.: Vipol. 1997. 196 s. (in Ukrainian).

3. V Minpryrody vidkrylasia vystavka, prysviachena stvorenniu Chornobylskoho radiatsiino-ekolohichnoho biosfernoho zapovidnyka [An exhibition dedicated to the creation of the Chornobyl radiation-ecological biosphere reserve opened in the Ministry of Natural Resources]. URL: file://localhost/E:/3\%20робстолу_червень\%202019/В\%20Мінприроди\% 20відкрилася\%20виставка,\%20присвячена\%20створенню\%20Чорнобил ьського\%20радіаційно-екологічного\%20біосферного\%20заповідника \% $20-\% 20 Н$ овини\%20-\%20Міністерство\%20екології\%20та\%20природних\% 20ресурсів\%20України.mht (data zvernennia:13.11.2019) (in Ukrainian).

4. Vorobiov Ye.O. ta in. Ekosystemy Chornobylskoho radiatsiinoekolohichnoho biosfernoho zapovidnyka: kryzovi yavyshcha mynuloho suchasnosti ta shliakhy optymizatsii [Ecosystems of the Chornobyl Radiation-Ecological Biosphere Reserve: Crisis Phenomena of the Past and Present and Ways of Optimization] / Ye.O. Vorobiov, S.M. Bidna, D.O. Vyshnevskyi, S.O. Yevdokymova, O.A. Borsuk. URL: https://zapovidnyk.org.ua/index.php?fn=novp\&f=php\&pid=2019-04-16-1932-40-3325 (data zvernennia: 13.11.2019) (in Ukrainian).

5. Dyrektyva Rady $92 / 43 /$ leEC pro zberezhennia dykyh ptahiv. URL: https://menr.gov.ua/news/31295.html (data zvernennia: 13.11.2019) (in Ukrainian).

6. Dyrektyva Rady 92/43/leEC pro zberezhennia pryrodnykh seredovyshch isnuvannia i dykoi fauny ta flory. URL: https://menr.gov.ua/ news/31295.html (data zvernennia: 13.11.2019) (in Ukrainian).

7. Naukovo-praktychnyi komentar do Zakonu Ukrainy "Pro okhoronu navkolyshnoho pryrodnoho seredovyshcha" [Scientific and Practical Commentary to the Law of Ukraine "On Environmental Protection"] / N.R. Malysheva, M.I. Yerofyeyev. Kh.: Pravo. 2017. 417 c. (in Ukrainian).

8. Polozhennia pro Chornobylskyi radiatsiino-ekolohichnyi biosfernyi zapovidnyk, zatverdzhene Nakazom Ministerstva ekolohii ta pryrodnykh resursiv Ukrainy vid 3 liutoho 2017 r. № 43. URL: http://zapovidnyk.org.ua/index.php?land=uk\&fn=novp\&pid=2019-04-1620-04-58-7371 (data zvernennia: 13.11.2019) (in Ukrainian).

9. Pozniak E.V. Problemy ekoloho-pravovoi kultury pryrodnozapovidnoi spravy. Aktualni problemy ekolohichnoho, zemelnoho ta ahrarnoho zakonodavstva $v$ suchasnych umovach [Problems of ecological and legal culture of nature conservation business in Ukraine]: materialy kruhloho stolu, prysviach. 90-richchiu $z$ dnia narodzh. d-ra iuryd. nauk, prof., chl.-kor. NAPrN Ukrainy V.K. Popova (Kharkiv, 1 berez. 2019 r.) / za zah. red. A. P. Hetmana I M.V. Shulhy. Kh.: Pravo. 2019. C. 166 - 169. (in Ukrainian).

10. Pravovyi rezhym pryrodno-zapovidnoho fondu Ukrainy: istoriia formuvannia, yurydychni aspekty ta zakordonnyi dosvid [Legal regime of the Natural Reserve Fund of Ukraine: history of formation, legal aspects and foreign experience] (posibnyk) / za zah. red. O. Kravchenko. Lviv: "Vydavnytstvo "Kompania Manuskrypt". 2017. 92 s. (in Ukrainian).

11. Snizhko V.V. Narysy z psyhoetnichnoi ekolohii Ukrainy [Essays on psycho-ethnic ecology of Ukraine]. K.: Veselka. 2001. 334 s. (in Ukrainian).

12. Taras Melnychuk: "Iz zony vidchuzhennia namahaiemosia zrobyty zonu vidrodzhennia": Chym zhyve sohodni, shcho planuie na maibutnie ta yak dolaie pereshkody novostvorenyi zapovidnyk: interviu ochilnyka Chornobylskoho radiatsiino-ekolohichnoho biosfernoho zapovidnyka T. Melnychuka zhurnalu "Pozhezhna ta tekhnohenna bezpeka" [From the Exclusion Zone, We Are Trying to Make the Renaissance Zone ": What is the Future, Planning for the Future, and How Does the Obstacle Overcome the Living Reserve?]. URL: https://zapovidnyk.org.ua/index.php?fn= novp\&f=php\&pid=2019-04-16-19-58-58-9209 (data zvernennia: 13.11.2019) (in Ukrainian).

13. Chornobylskyi radiatsiino-ekolohichnyi biosfernyi zapovidnyk [Chornobyl radiation-ecological biosphere reserve]. URL: https://zapovidnyk.org.ua/ (data zvernennia:13.11.2019) (in Ukrainian).

14. Kovalenko T.O., Tamburelli G. La creazione di una riserva UNESCO della biosfera in Ucraina. Gazzetta Ambiente. 2018. № 2. 135144. URL: URL: http://www.gazzettaambiente.it/scheda.cfm?id=1248\& la_creazione_di_una_riserva_unesco_della_biosfera_in_ucraina (data zvernennia:13.11.2019) (in Italian)

Received: $14 / 11 / 2019$ Accepted: $15 / 12 / 2019$

E. Pozniak, PhD (Law), Associate prof., psychologist

Taras Shevchenko National University of Kyiv, Kyiv, Ukraine

\section{ECOLOGICAL AND LEGAL CULTURE OF NATURAL RESERVEATION IN UKRAINE (ON THE EXAMPLE OF CHORNOBYL RADIATION AND ECOLOGICAL BIOSPHERE RESERVE)}

The paper deals with the analysis of innovations in legal regulation for formation and providing of activities of Chornobyl Radiation and Ecological Biosphere Reserve within the Exclusion Zone and the Zone for the Unconditional (Obligatory) Resettlement in Ukraine.

Special attention is paid to the legal regime of Biosphere reserve, that provides the following: the national and international level of the legal protection and reproduction of fauna and flora and their habitat; preservation and reproduction of wildlife objects, included in the Red Book of the Threatened Animals and Plants; fundamental scientific research conducting and the prediction of further changes in the species and population status of wild animals and plants world; development of the ecological and legal culture of the society and individuals as a result of organization and implementation by the said Reserve of informational, educational, recreating, touristic, educational, and cognitive activities.

At the same time, this Biosphere reserve was created within a territory that for a long time has been ecologically and radioactively dangerous. The legal regime in Chornobyl Zone has provided a number of restrictions for living and performing certain types of activities. The author emphasizes the need for deeper research of on the issue of the safety level for wild animals and plants within the area of the said Reserve, as well as the development of criteria for assessing the environmental and radioactive safety for wildife.

Keywords: biodiversity, Chornobyl Radiation and Ecological Biospherical Reserve, Chornobyl Zone, ecological and legal culture, ecological and radioactive safety, nature reserve fund, radioactively contaminated territories, wild animals and plants. 